\title{
"Don't confuse me with facts"-how right wing populism affects trust in agencies advocating anthropogenic climate change as a reality
}

Olve Krange ${ }^{1 凶}$, Bjørn P. Kaltenborn ${ }^{1} \&$ Martin Hultman ${ }^{2}$

Everyday public denial of anthropogenically caused climate change (ACC) has complex antecedents and exists on both individual and institutional levels. Earlier research has linked ACC denial to opposition to formal science and elites, perceived threats to the industrialist capitalist order and existing system properties. Research also suggest that trust in public organizations is a key factor in determining support or opposition to climate change policies. In this paper, we explore the possibility that right wing populism and anti-elitist attitudes fuel both ACC denial and low trust in environmental institutions. We surveyed a representative sample of Norwegians $(N=3032)$ to measure ACC denial, how denial is linked to socio-demographic characteristics, trust in environmental institutions, attitudes toward elites and immigration, as well as environmental attitude orientations. Results show that lack of trust in environmental institutions is strongly associated with ACC denial, and furthermore that the degree of trust-or lack thereof-is partly a function of anti-elitist attitudes, opposition to migration and views of nature.

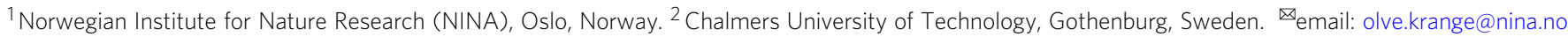




\section{Introduction}

limate change (CC) has emerged as the foremost global environmental issue during the last three decades. Lately, the widespread concern over CC is accompanied by an equally grave and growing worry over landscape changes and habitat loss as perhaps the most important driver of CC (Stoddard et al., 2021). Collectively, the climate crisis and the nature crisis (Ruckelhaus et al., 2020) confront humanity with formidable challenges in terms of societal organization and political leadership. However, even after the last IPPC report (Sixth Assessment Report (ipcc.ch)) several political agents still refuse to recognize human activities as the most important driver of global warming, an undisputable fact in the IPCC reports. Often affiliated with right wing populist movements or parties they are frequently also outspoken anti-immigration and anti-elitist advocates, and do not hesitate to criticize scientists and scientific knowledge in general (ref. e.g. Covid 19 anti-vax hesitancy and organized aggression/Agius et al., 2020; Kallbekken and Sælen, 2021).

Norway offers a particularly interesting context for the study of ACC denial. On one hand Norway has an image as a green country, a generous donor of foreign aid to promote peace and sustainable development. On the other Norway's economy is strongly oil and gas-dependent, an industry which forms the economic basis for one of the world's most generous public welfare systems. The Norwegian population of five million emitted 7 tons of $\mathrm{CO}_{2}$ per capita per year in 2018. $\left(\mathrm{CO}_{2}\right.$ emissions (metric tons per capita)-Norway|Data (worldbank.org)), a rather high value compared to world average $\left(4.4 \mathrm{CO}_{2}\right.$ per capita/ $\mathrm{CO}_{2}$ emissions (metric tons per capita)|Data (worldbank.org)). Many factors influence public opinions about and trust in science: Affluent $\mathrm{CO}_{2}$-dependent lifestyles, strong scientific evidence for anthropogenically induced climate change (ACC) and global warming, a political elite surpassing the antagonism between oil and gas extraction and CCA and huge revenues from oil and affiliated industries (Listhaug, 2005; Thurber et al., 2011).

CC denial and underlying values are not restricted to populist parties and may be labeled 'mainstream populism' or demoticism (March, 2017). Agents of ACC skepticism, strict immigration laws, anti-elitism and skepticism towards scientist and scientific knowledge can be found across the political spectrum. However, in Norway as in many other countries, this is more prevalent on the right wing of the political spectrum. One political party in particular not only is strongly skeptical of ACC and science in general, but also voice strong support for continued oil-and gas production, as well as a suite of other illiberal political positions.

This persistent and complex challenge of the combined climate and nature crisis exposes science and research to public scrutiny. The CC narrative has found its way into most political sectors with significant impacts on policies, strategies and actions affecting budgets and livelihoods of large populations. There is broad consensus about anthropogenic climate change (ACC) among scientists, and while a substantial part of the public is still skeptical, significant portions of the public believe that CC is real, that it is caused by human activity, and that collective political action now needs to take place (Anderegg et al., 2010; Poortinga et al., 2011; Capstick and Pidgeon, 2014; Tranter and Booth, 2015). Recent data from the US show that 72 percent take as a fact that global warming is happening, and 57 percent accept as true that it is caused by humans (Yale Program on Climate Change Communication, 2020). This mirrors the trends found in a range of other countries. Across the globe, the portion of the public who believes that humans have no hand in CC is consistently $<10$ per cent (YouGov, 2019).

As with many other societal risks the complex nature of ACC makes it hard for non-experts to assess and fully understand its causes, risks, magnitudes and timeframes. CC impacts are often psychologically-as well as physically distant, yet simultaneously frightening to many, regardless of political orientation (Spence et al., 2011; Marshall, 2014; Stoknes, 2015; Lindvall et al., 2020). Also, some researchers have argued that the dominant CC discourses which focus on technological fixes, neoclassic economical solutions and changing the culture of consumption do not necessarily advance social change since they represent particular norms and value sets to which parts of the public do not subscribe (Fleming et al., 2014). These dominant discourses emphasize lack of information and science, as well as consumerism. They further argue that the language used by different social groups is not recognized by the dominant CC discourses. Hence lay people are not accepted as legitimate producers of knowledge (Fleming et al., 2014), which may alienate certain groups and compound the resistance against elites and established institutions.

Distrust in climate science results has increasingly become an ideology marker, a position taken by default if you consider yourself a right-wing or conservative voter (McCright et al., 2016; Sheldon and Oreskes, 2017; Lockwood, 2018; Hultman, 2020; Graça, 2021). However, these kinds of analysis need to be nuanced (Huber, 2020; Vihma et al., 2021). Some groups in society strive to defend the industrialist capitalist order from the claims of environmental groups, and therefore doubt or reject all social and natural science that underpins issues like CC. Paradoxically, at least in terms of belief in science as a mode of knowledge production, the same groups support and believe in science that provides instruments for economic production (McCright et al., 2013; Forchtner et al., 2018).

Trust plays a critical role in communicating science to the public. Whether or not people trust organizations and individuals that communicate ACC is a critical condition in terms of support and opposition to the CC narrative (Marshall, 2014). Here we understand trust as an attitude, a form of openness to new knowledge and intentions by persons, social groups or institutions. Or in the words of Earle et al. (2010), a "willingness, in expectation of beneficial outcomes, to make oneself vulnerable to another based on a judgment of similarity of intentions or values". Trust can also be understood as a form of power exchange where one allows someone else "the benefit of the doubt" (Rahn and Transue, 1998), by accepting alternative information and its potential implications. A typical trait of the CC discourse is that most people typically have little knowledge of the complex scientific foundation for the ACC claim. As several authors have argued, trust can be seen as a form of 'standing decision' which provides a heuristic for evaluating conflicting scientific claims about the environment (Bord et al., 2000; Smith, 2002; Shwom et al., 2008). Trust helps alleviating uncertainty and improves the efficiency of information processing (Nyhan, 2000; Brewer and Ley, 2013).

In this paper, we aim for a deeper understanding of the relationship between ACC denial and trust in climate scienceexamining the relationship in the context of right wing populism and anti-elitism.

Populism (right wing) and CC denial. Populism is a fuzzy term. Our contribution is not on populism per se and we use the term populism rather loosely to denote popular opposition towards an illegitimate elite. In Western European countries populism has typically been associated with radical right wing parties. However, left as well as right leaning parties can utilize the idea that 'ordinary good people are ruled and exploited by an illegitimate corrupt elite' (paraphrasing Mudde, 2004) as core message in their effort to recruit voters. For instance, based on an analyses of 32 parties in five European countries Rooduijn and Akkerman 
(2017) found that parties from both ends of the political spectrum employed people-centered ant-elitist populist discourses in their communication. Similar findings are made in the UK (Gandesha, 2018).

Originally a phenomenon on the political fringes for a long time after the second world war, authoritarian nationalist parties now, in 2021 attract large groups of voters in an increasing number of countries. These parties have redrawn the political map around Europe, and they sail under different flags. Some of them - such as the National Assembly and the Sweden Democrats -have their roots in fascist and neo-Nazi circles. Parties such as the Danish People's Party and the Progress Party in Norway have above all grown out of dissatisfaction with tax policy. Later, they have moved to highlight their criticism of immigration policy, thereby merging with other similar parties. Mudde uses the term populist radical right, which he defines as nationalist, authoritarian and anti-elite. It is important to point out, as Mudde does, that it is a right-wing movement, as the populism that has emerged on the left, such as Podemos in Spain, Bernie Sanders in the United States or Jeremy Corbyn in Britain, has not had a climate-denying, xenophobic, or authoritarian appearance (Mudde, 2021).

A populist communication strategy is visible across the spectrum revolving around a juxtaposition of 'pure people' versus an 'evil', corrupt elite. (Huber et al., 2021). The populist far right seemingly believes that such an elite is responsible for the loss of economic competitiveness and hardship for individual members of the nation. The stretch is short from this outlook to it's the influence of right wing populism on CC skepticism, arguing that populist, anti-elite stances are driving climate skepticism. That is, populism in general is bad for the climate, irrespective of its host ideology, be it left or right (Huber, 2020). Populist elements are certainly present in far-right climate communication, others have convincingly shown that CC denial is most strongly predicted by exclusionary, anti-egalitarian preferences and nationalist attitudes which illustrates the significance of political ideology in relation to climate policy discourse and action (Jylhä and Hellmer, 2020; Kulin et al., 2021; Yan et al., 2021).

Research has shown that CC skepticism comes in a wellorganized and well-funded versions (e.g. the denial machine), as lay peoples skepticism and as forms of ideology (McCright and Dunlap, 2011; Capstick and Pidgeon, 2014; Tranter and Booth, 2015; Hultman et al., 2019). All levels of public resistance represent important barriers towards successful CC adaption and mitigation policies. Our assumption is that the trust in environmental organizations vary across the public in the sense defined by (Renn and Levine, 1991) that there are diverse views on whether the message in the CC discourse is true and reliable and that the communicating agencies demonstrate competence and honesty by conveying accurate, objective and complete information.

In this paper, we build on earlier research exploring the foundations of resistance against acknowledging and accepting ACC, which has shown that skepticism and denial can be linked to antecedents like early life socialization and cultural capital (e.g. Kaltenborn et al., 2017), protection of group identity and social systems providing desired benefits, as well as anti-elitism (e.g. McCright and Dunlap, 2011), lack of trust in formal science and institutions (e.g. Lacey et al., 2018; Smith and Mayer, 2018), and right wing populism and xenophobia (e.g. Forchtner, 2019; Jylhä et al., 2020; Malm, 2021).

Populist and extreme right wing movements tend to challenge the developments and changes proposed by more liberal forces and established institutions (Rydgren, 2005). In many cases, the very core of the mission of populist movements is the opposition to formal governance and scientific knowledge. We suggest in the context of CC that as an opposition movement, populism and extreme right wing groups express what they perceive as relative deprivation of societal goods compared to other groups, since they perceive that their way of life may be threatened if liberal forces succeed with their CC policies, arguing that it is not economic hardship or deprivation as such but the internalized fear of losing one's social status that makes people more prone to support populist ideas and parties (Lübke, 2021).

We also assume that the denial of ACC does not necessarily limit itself to a narrow battle over the dominant scientific truth that ACC is real. We suspect that as CC skepticism is woven into the fabric of a broader scope of resistance, therefore trust in established public institutions with responsibility for questions of environmental governance is a critical variable. Given the somewhat obscure and diffuse nature of CC impacts, most people are left to rest their opinions in the trust they have for experts and the various institutions that communicate ACC and implement actions that will affect our everyday life in the future. And this narrative is continually challenged by alternative "experts" claiming contradictory truths (Lamb et al., 2020).

The link between CC denial and xenophobic attitudes is well established within the international research literature (e.g. Forchtner and Kølvraa, 2015; Lockwood, 2018; Krange et al., 2018; Hultman et al., 2019; Hultman, 2020). The explanations vary a great deal, but many emphasize the fact that both measures to mitigate $\mathrm{CC}$ and immigration drive changes that affect different parts of the public to various degrees. The growing influence of the digitally based far-right media also appears to be a driving factor in Europe (Vowles and Hultman, 2021) a similar pattern as happened in the US some years before (Bloomfield and Tillery, 2019: Kaiser et al., 2020).

Xenophobic attitudes and opposition to immigration have been linked to the concept of relative deprivation, the idea that individuals or groups experience what they perceive as injustice (Walker et al., 2015). This is a sense of grievance about injustice or being marginalized in a way that is unfair, where one ends up worse than comparison groups. Multiculturalism and pluralist ideologies can threaten identity and ethnicity, and exacerbate inand out group distinctions (Pulé and Hultman, 2019). Anger and resentment from perceived deprivation can lead to social protest and resistance (Anshelm and Hultman, 2014; Daggett, 2018; Leviston et al., 2020). The concept is usually applied in contexts where individuals or groups can assess the fairness of an outcome relative to an imaginable outcome (Walker et al., 2015). Outcomes are typically distributive, for instance how will CC mitigation policies affect the access to non-renewable natural resources. Of relevance here is that both CC, immigration and established elites may all be perceived as proxies of the political majority, potentially threatening the existing social and political order in a way that can lead to relative deprivation of populist and right wing movements.

To examine these assumptions, we specifically ask what is the extent of CC denial among the Norwegian public, and how is CC denial linked to socio-demographic characteristics, trust in environmental institutions, attitudes toward elites and immigration, as well as environmental attitude orientations.

\section{Methods and data collection}

3032 Norwegians, aged 18-80, completed an online questionnaire in 2017 asking multiple questions about the environment and CC. Respondents were drawn from a nationally representative panel (TNS Gallup-panel) of 50,000 persons. Approximately 7704 respondents were contacted, leaving us with a 39 per cent response rate. The questionnaire was self-administered through an Internet solution. Respondents were called one extra time and 
the link was closed when target sample size was reached. Therefore, the response rate would have been higher if everyone who wanted to answer had been given the opportunity. An advantage of this procedure, however, is that sampling corrections can be made during the course of data collection if disproportions are observed. Our sample was stratified according to official Norwegian statistics, using age, sex, geography and level of education as stratification variables.

To cover both trend and attribution skepticism to CC we asked: Which of the following three statements do you personally believe? 'Climate change is happening now, caused mainly by human activities', 'climate change is happening now, but caused mainly by natural forces', 'climate change is not happening now' and unsure/don't have an opinion. In the following analyses we combine both trend and attribution skepticisms, where respondents who are either trend or attribution skeptics simply are called CC skeptics. We compare this group with the respondents who stated that they believe in anthropogenic CC (ACC), the non-skeptics. Respondents that did not fit into any of these categories (missing and the unsure) where removed from the sample. Leaving us with a net sample size of $n=2834$.

Table 1 provides the coding, mean and standard deviation for all the variables in the study.

We measured trust in expert knowledge as confidence in a set of agents and environmental institutions that represents the ACC scientific consensus. We asked: "What is your level of trust in the agents and institutions listed below?" Level of trust was indicated on a 5-point scale ranging from "very low trust" to "very high trust". We created the index "Trust in environmental institutions" based on responses to five institutions from the list: climate scientists, biologists, Norwegian Environment Agency, Ministry of Climate and Environment, and Friends of the earth (Norway). The index achieved a Cronbach's Alpha equal to 0.87. Sociodemographic characteristics included gender, age, education level, income status and place of residence size (rural-urban).

The questionnaire contained statements aimed to measure the respondents' overall views on nature. Here we have selected three formulations. On a five-point scale, respondents agreed or disagreed with the following statements: "Nature's balance is fragile and can be easily disturbed by human activities", "I think it is right that the intrinsic value of nature is one of the pillars in Norwegian conservation legislation" and "The idea that nature has intrinsic value is wrong." We constructed an index we call ecocentric view of nature that ranges from 0 to 4 . Agreement with ecocentrism increases with increasing score. The scale achieved a Cronbach's Alpha of 0.66 .

In Norway, as in many other western countries, loud and outspoken criticism of massive immigration, is characteristic of right leaning populist rhetoric. Respondents were asked to respond to the statement 'We have enough immigrants and asylum seekers in our country'. Level of agreement was reported on a five-point scale ranging from disagree strongly to agree strongly.

We operationalized "anti-elitism" by constructing an index based on the level of agreement with five statements: "The elites (within politics, management, business, etc.) determine the development of society at the expense of the minds of ordinary people", "Politicians are mostly concerned with securing their own interests", “Experts decide too much”, "Ordinary people are more honest than politicians" and "Lay knowledge is more sound than education". On all items respondents gave their opinion on a five point scale ranging from disagree completely to agree completely. The scale achieved a Cronbachs Alpha equal to 0.81 .

\section{Results}

Figure 1 shows that CC skepticism is still quite widespread in Norway, despite the overwhelming scientific evidence provided by IPPC over many years, and the extensive coverage of CC issues in media on all levels form the local to international coverage. The level of CC denial in the Norwegian public appears to have remained relatively stable for several years. In the current study, attribution skepticism counted for most the CC denial. More than 36 percent reported that they believed in CC but disagreed that human activities was the main cause. Trend skepticism on the other hand is very rare. Only 1.6 percent believe that CC does not happen at all. In a previous study of CC denial among Norwegians based on date from 2012, we found that 36 percent disagreed that CC is caused by humans, but a mere 1.1 per cent of the population totally rejected the existence of $\mathrm{CC}$ as a phenomenon (Krange et al., 2018).

The joint dichotomized ACC denial measure (Table 1) shows that 41 percent were either attribution or trend skeptics. However, note that the phrase "mainly caused by", since respondents who belong to this group do not necessarily totally reject the influence of human activities, but see it as less important than

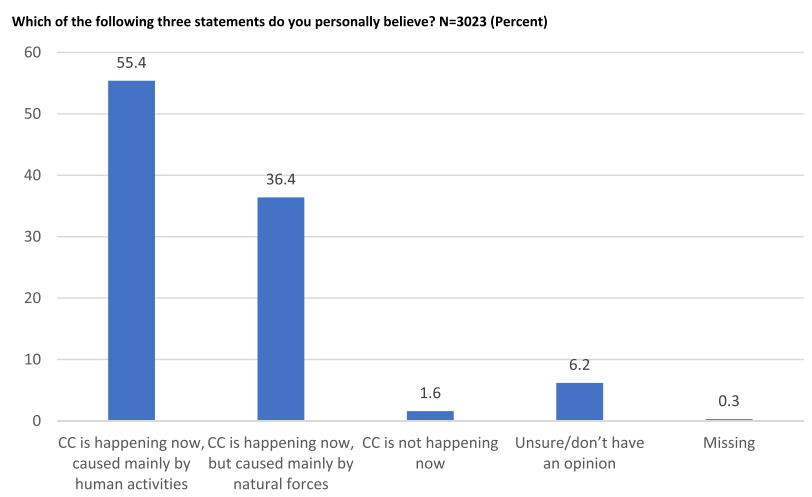

Fig. 1 Univariate prevalence. Which of the following three statements do you personally believe? $N=3023$ (percent).

Table 1 Coding, mean and standard deviation for variables in the study.

\begin{tabular}{|c|c|c|c|}
\hline Trust in environmental institutions & 0 (very low trust) to 4 (very high trust) & 2.33 & 0.85 \\
\hline Age & $18-80+$ (numbers inn actual years) & 49.44 & 16.44 \\
\hline Educational attainment & 0 (secondary school or less) to 3 (university 4 years + ) & 1.29 & 0.77 \\
\hline Annual income in NOK & $1(<200 k)$ to 9 (more than $1000 k)$ & 3.59 & 2.05 \\
\hline Place of residence (rural-urban) & $0(<200)$ to $6(>300,000)$ & 3.19 & 1.74 \\
\hline Anti-elitism & 0 (disagree strongly) to 4 (agree strongly) & 2.60 & 0.84 \\
\hline
\end{tabular}


"natural causes". So, we can ascertain that even after several decades of scientific research confirming human impact on CC and a very high degree of scientific consensus on the relationship between e.g. $\mathrm{CO}^{2}$ emissions and global warming, a substantial portion of Norwegians still disagrees with the overwhelming scientific consensus on the topic. Table 2 shows how CC skepticism correlates with trust and a range in socio-economic variables using bi-variate linear regression analyses (OLS). In this analysis CC denial is the dependent variable, where the effect of each of the independent variables are tested separately.

CC denial is clearly associated with a lack of trust in environmental institutions. As noted above, CC is a diffuse and complex phenomenon, seldom directly observable on an everyday life experience level. The causes and drivers of CC are even less tangible. Therefore, whether one believes in anthropogenically caused CC is a question of trust in formal science and established public institutions. The agents and institutions we have included in this study all communicate a coherent narrative that ACC has been confirmed beyond doubt and that society must take drastic action in order to avoid grave future consequences. Hence, the observed negative statistical association is as expected. However, these are also agencies with multiple responsibilities and interests in environmental issues, and consequently varying degree of influence on nature management policies. Because environmental regulations impact people's everyday life in any number of ways, there are several potential reasons to distrust them, and it is perfectly possible to combine lack of trust with the belief that ACC is a reality. But the strong effect from $(B=-1.35)$ and the $\mathrm{OR}$ at 0.26 suggests that this combination is not particularly prevalent.

The analyses indicate that CC skepticism is far more widespread among men than women. In general, survey research find

\begin{tabular}{|lrlll|}
\hline \multicolumn{2}{|l}{ Table 2 Bivariate logistic regressions (OLS). } & & \\
$\begin{array}{l}\text { Dependent variable: Climate change } \\
\text { skeptics }\end{array}$ & B & SE & Sig. & OR \\
\hline $\begin{array}{l}\text { Variables: Trust in environmental } \\
\text { institutions }\end{array}$ & -1.35 & 0.06 & 0.000 & 0.26 \\
Gender & 0.55 & 0.07 & 0.000 & 1.74 \\
Age & 0.02 & 0.00 & 0.000 & 1.02 \\
Educational attainment & -0.50 & 0.06 & 0.000 & 0.61 \\
Annual income in NOK & 0.07 & 0.08 & 0.000 & 1.08 \\
Place of residence (rural-urban) & -0.20 & 0.02 & 0.000 & 0.82 \\
Ecocentric view of nature & -1.56 & 0.07 & 0.000 & 0.21 \\
Immigrant skepticism & 0.54 & 0.04 & 0.000 & 1.71 \\
Anti-elitism & 0.89 & 0.05 & 0.000 & 2.044 \\
\hline
\end{tabular}

that CC denial and skepticism is gendered, but the methods used often only provide aggregate data about men and women.

One of the more striking examples is the so called "with male effects", a term used by McCright and Dunlap (2011). They reported that within elite groups conservative males were heavily overrepresented, suggesting that this was an expression of protecting group identity and justifying a societal system that provides desired benefits. Actions needed to mitigate the effects of CC requires social and economic change that threatens the groups that benefit from the existing social order, and it seems that this type of resistance is most strongly expressed by white, conservative men. Similar findings have been reported by us among Norwegians (Krange et al., 2018) and is more or less a global phenomenon as summarized in the term Industrial/ Breadwinner masculinities by Hultman and Pulé (2018). We also find statistically significant correlations between CC skepticism and all the other variables we included. The bivariate regression analysis indicates that the CC issue is heavily polarizing, with strong effects from other attitude variables, such as trust in environmental institutions, view of nature, skepticism towards immigrants, and anti-elitism, in addition to social variables such as educational attainment, gender, age and educational attainment. CC denial is positively correlated with lack of trust in environmental institutions, it increases with age, but it is negatively correlated with education, i.e. the higher the level of education, the less likely a person is to be skeptical to, or deny ACC. Furthermore, CC denial is positively correlated with opposition to elites and immigration, and a CC denier is more likely to live in a rural setting than an urban context. Views of nature also discriminates significantly, i.e. the more ecocentric attitudes a person expresses, the less likely he or she is to be CC denier.

We then performed a multiple regression analysis with four consecutive models on the same data set, again with CC denial as the dependent variable (Table 3 ). In this procedure the independent variables are entered stepwise so that we can observe how the contribution of each set of independent variables impacts the effect from the trust in environmental institutions variable. In the first model we entered only the 'Trust in environmental institutions' variable which produced a significant correlation with CC denial. The second model contained trust, gender, age, education, income and place of residence. In this model, the contribution of gender is not significant, but all the other independent variables influence the level of CC denial significantly. We also see that the effect of trust is slightly reduced as this variable is also influenced by other variables. In the third model we added the 'Ecocentrism' variable, which has a marked effect on the overall relationship. The effect of trust is still significant but is reduced compared to the second model. In the fourth model we added the remaining variables, 'Immigrant skepticism',

Table 3 Multippel logistic regressions (OLS).

\begin{tabular}{|c|c|c|c|c|}
\hline Dependent variable: Climate change skeptics & Model 1 B/SE/Sig. & Model 2 B/SE/Sig. & Model 3 B/SE/Sig. & Model 4 B/SE/Sig. \\
\hline Variables: Trust in environmental institutions & $-1.35(0.6)^{\star \star \star}$ & $-1.25(0.07)^{\star \star \star}$ & $-0.93(0.07)^{\star \star \star}$ & $-0.84(0.08)^{\star \star \star}$ \\
\hline Gender & & $0.05(0.11)^{\mathrm{ns}}$ & $0.02(0.11)^{\mathrm{ns}}$ & $0.04(0.11)^{\mathrm{ns}}$ \\
\hline Age & & $0.02(0.00)^{\star \star \star}$ & $0.02(0.00)^{\star \star \star}$ & $0.02(0.00)^{\star \star \star}$ \\
\hline Annual income in NOK & & $0.10(0.03)^{\star \star \star}$ & $0.10(0.03)^{\star \star}$ & $0.09(0.03)^{\star \star}$ \\
\hline Place of residence (rural-urban) & & $-0.07(0.03)^{\star}$ & $-0.08(0.03)^{\star}$ & $-0.08(0.03)^{\star}$ \\
\hline Ecocentric view of nature & & & $-1.12(0.08)^{\star \star \star}$ & $-1.10(0.09)^{\star \star \star}$ \\
\hline Constant & & $1.94(0.26)^{\star \star \star}$ & $4.36(34)^{\star \star \star}$ & $2.32(44)^{\star \star \star}$ \\
\hline
\end{tabular}


and 'Anti-elitism' which also prove to have significant effects on the prediction of CC denial, but the effect of trust is further reduced.

The analysis reveals several interesting findings. First, of all the independent variables included, gender is the only variable that does not correlate significantly with CC denial. Controlled for "trust in environmental institutions" gender have no impact as a predictor for the level of denial, and this holds for all four models of multiple regression. Second, CC denial forms statistically significant correlations with the other factors. Age, education, income and type of residence have some predictive power, and so do the attitude factors, trust in environmental organizations, views of nature, and skepticism towards immigration and elites. Trust in environmental organizations have significant predictive power in all four models. However, the analysis also shows that when more variables are added to the equation, and in particular ecocentrism, immigration skepticisms, and anti-elitism, the effect of trust is reduced. In other words, the level of trust in environmental institutions is to a considerable extent embedded in attitudes the respondents hold toward nature in general, elites, and immigration.

\section{Discussion}

To deny anthropogenic CC comprise rejection of what influential institutions like the IPCC and Norwegian environmental institutions consider a fact. Nevertheless, CC skepticism and denial of this kind is still relatively widespread among the Norwegian public and appears to have remained at a stable level during the past few years. Based on a study of rural communities in Norway, Norgaard (2011) showed how denial was produced and maintained on a national and local level. She observed a contradiction between beliefs and action concerning CC, and coined the term "socially organized denial" to explain how local actors such as politicians, newspapers and even teachers help communities find a way to overcome otherwise unpleasant antagonisms, for instance by obfuscating danger by endorsing technical solutions.

Similar contradictions and negotiations are currently played out on the national level. Representatives of the largest and most influential political parties, including members of government, maintain that Norwegian oil and gas production is "part of the climate solution" (Norsk sokkel-en del av løsningen-regjeringen.no). They claim that emissions from burning fossil fuel extracted on the Norwegian shelf is minor compared to other sources, such as polish brown coal (lignite) which use otherwise would increase. Hence, it is argued that Norwegian oil and gas extraction is not only beneficial to Norwegian economy, but also to global warming. More than ever, the ruling political elites are intensely preoccupied with trying to persuade the public that Norwegian climate policy is on a climate friendly track.

This study shows that denial of ACC is clearly associated with a lack of trust in environmental institutions. This is noteworthy as these professionals and institutions carry much of the responsibility for developing policies and implementing actions aimed at mitigating the impacts of CC. Environmental institutions and their staff produce and maintain a CC discourse that, as we have alluded to above, can appear as alienating and excluding to segments of the public who do not believe in the language often used at the science-policy interface, and who may hold other value sets and alternative beliefs about environmental processes.

As a response to lack of trust, it may seem logical to try to increase the legitimacy of such institutions through further emphasis on increased information, the role they play for the benefit of society, the graveness of the CC phenomenon and so on. However, this risks simply compounding part of the reason many people do not believe in or trust these institutions. Namely that environmental organizations represent instruments of power for a type of societal change that could lead to what certain groups perceive as relative depredation and loss of desired system properties and benefits (Stoddard et al., 2021). If current institutions enforce policies leading to societal change which is perceived as unjust and unfair, scientific evidence will not improve the legitimacy of their agenda (Newell et al., 2020).

All societal change creates new differences and changes in power balances. Aversion towards change in power positions has in previous research been connected to an 'identity-protection' behavior attracting older males to CC denial positions (e.g. Krange et al., 2018), but is not identified in the same way when trust is added as a factor. This difference might be interpreted as either another form of 'identity-protection' practice this time by women, or that we are currently dealing with a much broader ideological turn towards CC denial (Forchtner et al., 2018). Research in Sweden indicates that the commonality is exclusionary and anti-egalitarian preferences, conservative values, and antiestablishment attitudes as well as an anti-feminist standpoint connected to CC denial, but little connection to the men and women binary (Jylhä and Hellmer, 2020).

In parallel with the change required to mitigate global warming several other historical changes are prevalent these days, which also challenge people's ways of living and require individual-level changes and adaptations. Many populist movements have been fueled by the implications of CC the way they are framed by the majority political power (Huber, 2020). The increasing pressure to scale down and restructure sectors and industries causing unacceptable climate gas emissions will inevitably change many people's lifestyles. Another driver of societal and cultural change is the significant immigration of both refugees and people who, for other reasons, make it to the west (McCright and Dunlap, 2011; Krange et al., 2018). Such developments characterize sociodemocratic societies like Norway and are examples of phenomena that affect many people and receive great political attention and media coverage. These phenomena' are experienced by and challenge segments of the population differently.

While lack of trust in key organizations is an important finding by itself, we maintain that it is urgent to understand what other factors link to lack of trust, since trust in science can be influenced by political ideology, religion, cultural capital, and various socio-economic and socio-demographic factors (Brewer and Ley, 2013; McCright et al., 2013, 2016; Kaltenborn et al., 2017). In our analysis we observed that the effect of trust in environmental institutions was clearly reduced when we included the "ecocentric view of nature-variable" in the analysis (Boukala and Tountasaki, 2019). In other words, there is a clear statistical association between these views. Furthermore, we saw that immigrant skepticism also had a clear impact on trust. When we controlled for several other variables, the analysis further showed that attitudinal factors had stronger relationships with trust in organizations than sociodemographic factors. Other research have also shown that political factors are more important in explaining attitudes toward CC than sociodemographic variables (Hornsey et al., 2016; Beiser-McGrath and Huber, 2018).

We suspect that there might be a common latent variable behind lack of trust in public institutions that expresses more general resistance to change and potentially different distributions of contemporary societal benefits. Both opposition to modern environmentalism and anti-immigration attitudes carry elements of nostalgia, a yearning for "the good old days" (Vowles and Hultman, 2021). The former is the antithesis to the idea that nature has value in its own right, namely that nature is there to be used by people - "the old way "of looking at things (nature), a viewpoint associated with traditional ways of interacting with nature. The latter can be interpreted as an expression of yearning 
for society as it used to be in previous times-a country for Norwegians only, which is the basis for much right-wing political messaging today regarding the environment in France (Boukala and Tountasaki, 2019) and Denmark (Forchtner and Kølvraa, 2015) for example.

Betz and Johnson (2004) conclude that the higher objective of a nostalgic political ambition is to stop or reverse the social erosion that characterizes Western European liberal democracies. Similar observations have been made in Sweden (Elgenius and Rysgren, 2019) and have also been identified as a common feature of Brexit and Trump's election victory in the US (Kenny, 2017), aptly captured in the slogan Make America Great Again. A concurrent retrospective longing can also be said to apply to the ecocentric natural vision, a relatively new attraction of nature and an ethical framework that stands in sharp contrast to the traditional, instrumentally oriented exploitation of the nature and natural resources (Skogen et al., 2017).

Collectively, the breadth of research on CC skepticism and denial, resting on data from a range of contexts and cultures, suggests that the unwillingness to accept the human hand in CC may be part of a larger and perhaps higher order of resistance towards change and uncertainty about future livelihoods and the unknown. A possible interpretation is that some groups feel, or fear, a relative deprivation of benefits if major social (Wullenkord and Reese, 2021), political and economic conditions change as a response to a worsening environment through CC. The denial of CC change tends to be most strongly expressed in segments of the public with a conservative and right wing populist political orientation (Huber, 2020). These segments also tend to have stronger anti-elitist orientations, lack of confidence in science and low trust in environmental institutions (Mede and Schäfer, 2020), which represent the society's main instruments for mitigating CC impacts.

\section{Conclusion}

Trust in environmental organizations is affected by a range of factors including socio-demographic characteristics, ecocentric views of nature, and attitudes toward elites and immigration. We believe that the lack of trust in environmental organizations associate with right wing and populist attitudes in two important ways. First, environmental organizations are key instruments in mitigating the effects of $\mathrm{CC}$ and this challenges contemporary societal system properties, and is perceived by groups of conservatives as liberal elites forcing a type of relative deprivation upon conservatives.

Second, environmental organizations rest their mission and narrative on formal science. Both populist leaders and certain conservative public segments nourish rejection of scientific knowledge as the core of their respective beliefs and narratives, albeit in rather different forms. Public distrust in formal science has grown considerably during the last few decades as alternative forms of knowledge compete for attention and legitimacy (Arimoto and Sato, 2012; Ravetz and Saltelli, 2015). The reasons are complex and relate both to rivaling political agendas, as the perceived inability of governing institutions to solve major societal issues and anti-elitism and ant-intellectualism (Merkley, 2020). Lack of trust in science has evolved on multiple levels from special interest groups and lay people to right wing governments to the extent of institutionalized 'war on science' (Mooney, 2005; Mede and Schäfer, 2020). Institutionalized, everyday denial, may also play a role (Thøgersen et al., 2021).

While the CC denial machine is well-funded and set up to produce "counter truths", lay skepticism constitutes the level where such "counter truths" are received, supported and given legitimacy. Hence, lay peoples' CC denial is, at least partly, a question of whom to trust in these matters. Trust is very much connected to sources of information of lately digital ones seems to be of great importance (Shah et al., 2021; Vowels and Hulman, 2021). This becomes a two-way relationship: Organized disinformation manufactures uncertainty. It helps generate skepticism among laypeople and therefore also among politicians that see denialists as important segments of their electorate and opposition towards liberals in power. This phenomenon is not restricted to the CC realm, but has been identified across multiple environmental arenas, where the production and propagation of scientific uncertainty has been used purposely by illiberal actors to question the legitimacy of progressive social and environmental reform (Oreskes and Conway, 2010).

\section{Data availability}

The datasets analyzed during the current study are not yet publicly available but are preliminary available from the corresponding author on reasonable request. The data set will in the future be available from the Norwegian Centre for Research Data (About NSD-Norwegian Centre for Research Data|NSD).

Received: 12 April 2021; Accepted: 11 October 2021; Published online: 29 October 2021

\section{Note}

1 Data was collected in cooperation with TNS Gallup Norway which is ISO certified by the standards ISO 9001:2008, ISO 20252 (Sector standard) and ISO 26362 (the Gallup panel that are used for this study). TNS Gallup always follows the existing directives from The Norwegian Data Protection Authority (NSD), and is controlled annually according to the Sarbanes-Oxley directive. All participants in the present study are anonymous to the research team.

\section{References}

Agius C, Rosamond AB, Kinnvall C (2020) Populism, ontological insecurity and gendered nationalism: masculinity, climate denial and Covid-19. Politics Relig Ideol 21(4):432-450

Anderegg WRL, Prall JW, Harold J et al. (2010) Expert credibility in climate change. Proc Natl Acad Sci USA 107(27):12107-12109

Anshelm J, Hultman M (2014) A green fatwā? Climate change as a threat to the masculinity of industrial modernity. NORMA 9(2):84-96

Arimoto T, Sato Y (2012) Rebuilding public trust in science for policy making. Science 337:1176-1177

Beiser-McGrath LF, Huber RA (2018) Assessing the relative importance of psychological and demographic factors for predicting climate and environmental attitudes. Clim Change 149(3-4):335-347

Betz H-G, Johnson C (2004) Against the current-stemming the tide: the nostalgic ideology of the contemporaryradical populist right. J. Political Ideol. 9(3):311-327. https://doi.org/10.1080/1356931042000263546

Bloomfield EF, Tillery D (2019) The circulation of climate change denial online: rhetorical and networking strategies on Facebook. Environ Commun 13(1):23-34

Brewer PR, Ley BL (2013) Whose science do you believe? Explaining trust in sources of scientific information about the environment. Sci Commun 35(1):115-137

Bord RJ, O'Connor RE, Fisher A (2000) In what sense does the public need to understand global climate change? Public Underst Sci 9:205-218

Boukala S, Tountasaki E (2019) From Black to green-analysing Le Front National's 'Patriotic Ecology'. In: Forchtner B (ed) The far right and the environment: politics, discourse and communication. Routledge, Abingdon, pp. $72-87$

Capstick SB, Pidgeon NF (2014) What is climate change skepticism? Examination of the concept using mixed methods study of the UK public. Global Environ Change 24:389-401

Daggett C (2018) Petro-masculinity: fossil fuels and authoritarian desire. Millennium 47(1):25-44

Earle M, Siegrist TC, Gutscher H (2010) Trust, risk perception, and the TCC model of cooperation. In: Earle M, Siegrist TC, Gutscher H (eds.) Trust in risk management: uncertainty and scepticism in the public mind. Earthscan, London, pp. 1-49 
Elgenius G, Rysgren J (2019) Frames of nostalgia and belonging: the resurgence of ethno-nationalism in Sweden. Eur Soc 21(4):583-602. https://doi.org/ 10.1080/14616696.2018.1494297

Fleming A, Vanclay F, Hiller C et al. (2014) Challenging dominant discourses of climate change. Clim Change 127:407-418

Forchtner B, Kølvraa C (2015) The nature of nationalism: populist radical right parties on countryside and climate. Nat Cult 10(2):199-224

Forchtner B, Kroneder A, Wetzel D (2018) Being skeptical? Exploring far-right climate-change communication in Germany. Environ Commun 12(5):589-604

Forchtner B (ed) (2019) The far right and the environment politics, discourse and communication. Routledge, London

Gandesha S (2018) Understanding right and left populism. In: Morelock J (ed.) Critical theory and authoritarian populism. University of Westminster Press, London, pp. 49-70.

Graça J (2021) Opposition to immigration and (anti-) environmentalism: an application and extension of the social dominance-environmentalism nexus with 21 countries in Europe. Appl Psychol 70(2):905-928

Hornsey MJ, Harris EA, Bain PG, Fieldiing KS (2016) Meta-analysis of determinants and outcomes of belief in climate change. Nat Clim Change 8:614-620

Huber RA (2020) The role of populist attitudes in explaining climate change skepticism and support for environmental protection. Environ Politics 29(6):959-982. https://doi.org/10.1080/09644016.2019.1708186

Huber R, Maltby T, Szulecki K, Cetković S (2021) Is populism a challenge to European energy and climate policy? Empirical evidence across varieties of populism. J Eur Public Policy https://doi.org/10.1080/13501763.2021.1918214

Hultman M, Björk A, Viinikka T (2019) The far right and climate change denial. Denouncing environmental challenges via anti-establishment rhetoric, marketing of doubts, industrial/breadwinner masculinities enactments and ethno-nationalism. In: Forchtner B (ed) The far right and the environment politics, discourse and communication. Routledge, London

Hultman M (2020) El viaje de la derecha nacionalista al ecocidio.: El caso de los Demócratas de Suecia (Sverigedemokraterna). Ecol Polít 59:101-106

Hultman M, Pulé P (2018) Ecological masculinities. Routledge, London

Jylhä KM, Strimling P, Rydgren J (2020) Climate change denial among radical right-wing supporters. Sustainability 2020 12(23):10226. https://doi.org/ $10.3390 /$ su122310226

Jylhä KM, Hellmer K (2020) Right-wing populism and climate change denial: the roles of exclusionary and anti-Egalitarian preferences, conservative ideology, and antiestablishment attitudes. Anal Soc Issues Public Policy 20(1):315-335. https://doi.org/10.1111/asap.12203

Kaiser J, Rauchfleisch A, Bourassa N (2020) Connecting the (far-) right dots: a topic modeling and hyperlink analysis of (far-) right media coverage during the US elections 2016. Digit Journalisms 8(3):422-441

Kallbekken S, Sælen H (2021) Public support for air travel restrictions to address COVID-19 or climate change. Transp Res Part D 93:102767

Kaltenborn BP, Krange O, Tangeland T (2017) Cultural capital and public trust shape attitudes toward climate change and preferred futures. A case study among the Norwegian public. Futures 89:1-13

Kenny, Paul D. 2017. Populism and Patronage: Why Populists Win Elections in India, Asia, and beyond. Oxford:Oxford University Press.

Krange O, Kaltenborn BP, Hultman M (2018) Cool dudes in Norway: climate change denial among conservative Norwegian men. Environ Sociol 5(1):1-11

Kulin J, Sevä IJ, Dunlap R (2021) Nationalist ideology, rightwing populism, and public views about climate change in Europe. Environ Politics https://doi.org/ 10.1080/09644016.2021.1898879

Lacey J, Howden M, Cvitanovic C, Colvin RM (2018) Understanding and managing trust at the climate science-policy interface. Nat Climate Change $8: 22-28$

Lamb WF, Mattioli G, Levi S (2020) Discourses of climate delay. Global Sustainability $3: 1-5$

Leviston Z, Dandy J, Jetten J et al. (2020) The role of relative deprivation in majority-culture support for multiculturalism. J Appl Soc Psychol. $50: 228-239$

Lockwood M (2018) Right-wing populism and the climate change agenda: exploring the linkages. Environ Politics 27(4):712-732

Lindvall D, Vowle K, Hultman M (2020) Upphettning. Demokratin i klimatkrisens tid. Fri Tanke förlag, Stockholm

Listhaug O (2005) Oil wealth dissatisfaction and political trust in Norway: a resource curse? West Eur Politics 28(4):834-851. https://doi.org/10.1080/ 01402380500216955

Lübke C (2021) Socioeconomic roots of climate change denial and uncertainty among the European population. Eur Sociol Rev. https://doi.org/10.1093/esr/ jcab035

Malm A (2021) White skin, black fuel: on the danger of fossil fascism. Verso Books.

March L (2017) Left and right populism compared: the British case. Br J Politics Int Relat 19(2):282-303
Marshall G (2014) Hear no climate evil. New Sci 223(2982):24-25

Mede NG, Schäfer MS (2020) Science-related populism: conceptualizing populist demands toward science. Public Underst Sci 29(5):473-491

Merkley E (2020) Anti-intellectualism, populism, and motivated resistance to expert consensus. Public Opinion Q 84(1):24-48

Mooney C (2005) The republican war on science. Basic Books, New York

McCright AM, Dunlap RE (2011) Cool dudes: the denial of climate change among conservative white males in the United States. Glob Environ Change 21(4):1163-1172

McCright AM, Dentzman K, Charters M et al. (2013) The influence of political ideology on trust in science. Environ Res Lett 8:044029

McCright AM, Dunlap RE, Marquart-Pyatt ST (2016) Political ideology and views about climate change in the European Union. Environ Politics 25(2):338-358

Mudde C (2004) The populist zeitgeist. Government Oppos 39:542-563

Mudde C (2021) Populism in Europe: an illiberal democratic response to undemocratic liberalism (The Government and Opposition/Leonard Schapiro Lecture 2019). Government Oppos 1:21

Newell P, Srivastava S, Naess LO, Torres Contreras GA, Price R (2020) Towards transformative climate justice: key challenges and future directions for research. Institute of Development Studies.

Norgaard KM (2011) Living in denial: climate change, emotions, and everyday life. MIT Press, Cambridge

Nyhan RC (2000) Changing the paradigm: trust and its role in public sector organizations. Am Rev Public Adm 30(1):87-109

Oreskes N, Conway EM (2010) Merchants of doubt-how a handful of scientists obscured the truth on issues from tobacco smoke to global warming. Bloomsbury Press, New York

Poortinga W, Spence A, Whitmars L et al. (2011) Uncertain climate: an investigation into public skepticism about anthropogenic climate change. Global Environ Change 21(3):1015-1024

Pulé P, Hultman M (2019) Industrial/breadwinner masculinities: understanding the complexities of climate change denial. In: Kinnvall C, Rydstrom H eds Climate hazards, disasters, and gender ramifications. Routledge, London

Renn O, Levine D (1991) Credibility and trust in risk communication In: Kasperson RE, Pieter JMS (eds) Communicating risks to the public. Springer.

Rahn WM, Transue JE (1998) Social trust and value change: the decline of social capital in American youth, 1976-1995. Political Psychol 19(3):545-565

Ravetz J, Saltelli A (2015) The future of public trust in science. Nature 524:161. https://doi.org/10.1038/524161d

Rooduijin M, Akkerman T (2017) Flank attacks: populism and left-right radicalism in Western Europe. Party Politics 23(3):193-204

Ruckelhaus MH, Jackson SJ, Mooney HA et al. (2020) The IPBES global assessment: pathways to action. Trends Ecol Evol 35(5):407-414

Rydgren J (2005) Is extreme right-wing populism contagious? Explaining the emergence of a new party family. Eur J Political Res 44(3):413-437

Shah M, Seraj S, Pennebaker JW (2021) Climate denial fuels climate change discussions more than local climate-related disasters. Front Psychol. https:// doi.org/10.3389/fpsyg.2021.682057/full

Shwom R, Dan A, Dietz T (2008) The effects of information and state of residence on climate change policy preferences. Clim Change 90:343

Sheldon MP, Oreskes N (2017) The religious politics of scientific doubt. In: Hart J (ed) Religion and ecology, Wiley Online Library, Ch. 25

Skogen K, Krange O, Figari H (2017) Wolf conflicts. A sociological study. Berghahn Books, New York

Spence A, Poortinga W, Pidgeon N (2011) The psychological distance of climate change. Risk Anal 32(6):957-972

Stoddard I, Anderson K, Capstick S, Carton W, Depledge J, Facer K,... \& Williams M (2021) Three decades of climate mitigation: why haven't we bent the global emissions curve? Annu Rev Environ Resour 46

Stoknes PE (2015) What we think about when we try not to think about global warming: toward a new psychology of climate action. Vt. Chelsea Green Books, White River Junction

Smith ERAN (2002) Energy, the environment, and public opinion. Rowman \& Littlefield, New York

Smith EK, Mayer A (2018) A social trap for the climate? Collective action, trust and climate change risk perception in 35 countries. Global Environ Change 49:140-153

Tranter B, Booth K (2015) Scepticism in a changing climate: a cross-national study Global Environ Change 33:154-164

Thurber MC, Hults DR, Heller PRP (2011) Exporting the "Norwegian Model": the effect of administrative design on oil sector performance. Energy Policy 39(9):5366-5378. https://doi.org/10.1016/j.enpol.2011.05.027

Thøgersen J, Vatn A, Aasen M, Dunlap R, Fisher DR, Hellevik O, Stern P (2021) Why do people continue driving conventional cars despite climate change? Social-psychological and institutional insights from a survey of Norwegian commuters. Energy Res Soc Sci 79:102168. https://doi.org/10.1016/ j.erss.2021.102168 
Vihma A, Reischl G, and Andersen AN (2021) A climate backlash: comparing populist parties' climate policies in Denmark, Finland, and Sweden. J Environ Dev 10704965211027748

Vowles K, Hultman M (2021) Scare-quoting climate: the rapid rise of climate denial in the Swedish far-right media ecosystem. 3(1), 79-95 https://doi.org/ 10.2478/njms-2021-0005

Walker I, Leviston Z, Price J et al. (2015) Responses to a worsening environment: relative deprivation mediates between place attachment and behaviour. Eur J Soc Psychol 45(7):833-846

Wullenkord MC, Reese G (2021) Avoidance, rationalization, and denial: defensive selfprotection in the face of climate change negatively predicts pro-environmental behavior. J Environ Psychol https://doi.org/10.1016/j.jenvp.2021.101683

Yale Program on Climate Change Communication (2020) https:// climatecommunication.yale.edu/visualizations-data/ycom-us/

Yan P, Schroeder R, Stier S (2021): Is there a link between climate change scepticism and populism? An analysis of web tracking and survey data from Europe and the US, Information, Communication \& Society, https://doi.org/ $10.1080 / 1369118 X .2020 .1864005$

YouGov (2019) Science and environment. International Poll in 28 countries on attitudes toward climate change. https:/yougov.co.uk/topics/science/articlesreports/2019/09/15/international-poll-most-expect-feel-impact-climate

\section{Acknowledgements}

This study was supported by The research Council of Norway (project Climate Ecotones, project no. 160022/F40), The Norwegian institute for Nature Research, Swedish Energy Agency (project no. 46178-1) and Formas (The Swedish Research Council for Sustainable Development, project no. 2018-00417)

\section{Competing interests}

The authors declare no competing interests.

\section{Additional information}

Correspondence and requests for materials should be addressed to Olve Krange.

Reprints and permission information is available at http://www.nature.com/reprints

Publisher's note Springer Nature remains neutral with regard to jurisdictional claims in published maps and institutional affiliations.

(c) (i) Open Access This article is licensed under a Creative Commons Attribution 4.0 International License, which permits use, sharing, adaptation, distribution and reproduction in any medium or format, as long as you give appropriate credit to the original author(s) and the source, provide a link to the Creative Commons license, and indicate if changes were made. The images or other third party material in this article are included in the article's Creative Commons license, unless indicated otherwise in a credit line to the material. If material is not included in the article's Creative Commons license and your intended use is not permitted by statutory regulation or exceeds the permitted use, you will need to obtain permission directly from the copyright holder. To view a copy of this license, visit http://creativecommons.org/ licenses/by/4.0/.

(c) The Author(s) 2021 